\title{
Zimbabwe's Export Performance: The Impact of the Parallel Market and Governance Factors
}

Sònia Muñoz 



\title{
IMF Working Paper
}

\author{
African Department
}

\section{Zimbabwe's Export Performance: The Impact of the Parallel Market and Governance Factors}

\author{
Prepared by Sònia Muñoz ${ }^{1}$ \\ Authorized for distribution by Sharmini Coorey \\ January 2006
}

\begin{abstract}
This Working Paper should not be reported as representing the views of the IMF. The views expressed in this Working Paper are those of the author(s) and do not necessarily represent those of the IMF or IMF policy. Working Papers describe research in progress by the author(s) and are published to elicit comments and to further debate.
\end{abstract}

This paper analyzes Zimbabwe's export performance in recent years and identifies the factors that could improve export performance, from both a quantitative and qualitative perspective. Improving export performance is critical to a turnaround in Zimbabwe's economic situation. The growth rate of total exports declined dramatically in the early 2000s, following a large real appreciation of the currency and the introduction of the fast-track land reform program. An important finding of the paper is that policies that reduce (eliminate) the parallel market premium and lower ethnic tensions would be key to promoting export growth.

JEL Classification Numbers: C33, F12, O17, O24, Q34

Keywords: Exports, Parallel Market, Governance, Competitiveness

Author(s) E-Mail Address: smunoz@imf.org

\footnotetext{
${ }^{1}$ I am grateful to Sharmini Coorey for very helpful discussions and suggestions and providing some of the data. I would also like to thank Paul Heytens and Markus Haacker for useful comments. The usual disclaimer applies.
} 


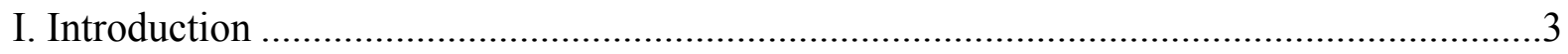

II. Export Performance in Zimbabwe …..................................................................

III. Analysis of the Determinants of Export Behavior ...................................................... 7

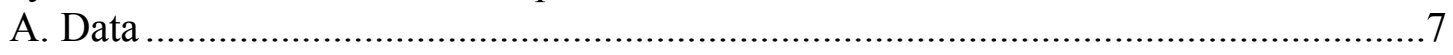

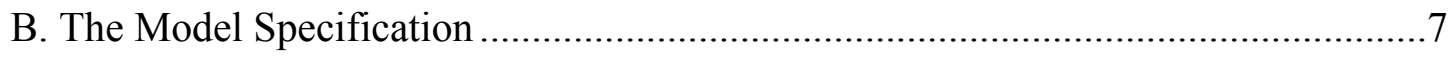

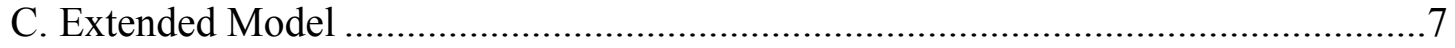

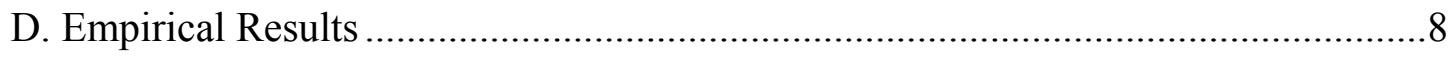

IV. Comparative Measures of Competitiveness ........................................................... 10

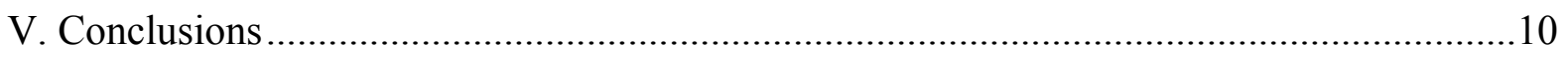

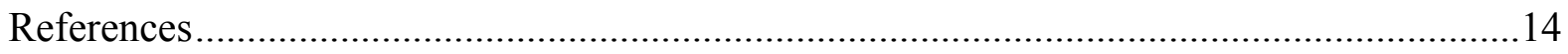

Tables

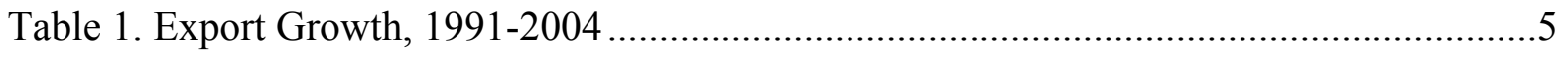

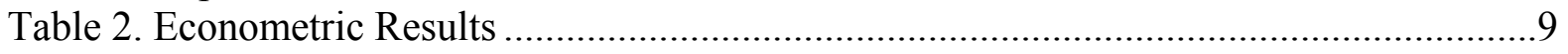

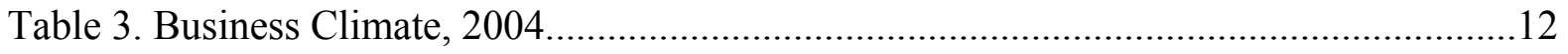

Figures

Figure 1. Exports and Real Effective Exchange Rate..................................................6



Appendices

I. Description of Sources and Transformation...............................................................13 


\section{INTRODUCTION}

Empirical studies have found that real exchange rate misalignment is negatively related to economic growth (Frenkel and Khan (1990), Cotanni et al. (1990), Edwards (1988)). In particular, Ghura and Grennes (1993) found that different measures of real exchange rate misalignment and its instability have negative effects on the growth rate of real per capita income, exports, and agricultural output as well as on investment for a sample of 33 subSaharan African countries including Zimbabwe. Misalignment of the exchange rate means lower profitability in the sectors whose output prices are lowered relative to prices in other sectors. Very often, misalignment takes the form of domestic currency overvaluation, which hurts tradable activities. This affects growth performance adversely since productivity improvements tend to be concentrated in export or import-competing industries. Moreover, distorted exchange rates have negative indirect effects usually referred to as smuggling activities that cause the supply of goods to legal or official markets to fall.

However, all these studies are based on cross-country data. It is possible that differences in the structure of economies, unrelated to real exchange rate misalignment, may explain the crosscountry differences in economic performance. It is therefore important to complement crosscountry studies on the relationship between exchange rate misalignment and economic performance with those using country-specific analyses in order to increase confidence in the estimated relationships.

Zimbabwe's experience provides a typical example of a country that has pursued inappropriate foreign exchange policies and suffered as result of these policies. Owing to foreign exchange controls in Zimbabwe, there has been always a black market for foreign currencies which is dominated by the U.S. dollar. Before the start of the fast-track land reform in 2000, the official and the black market value of the Zimbabwean dollar were close (about Z\$40 per US\$1). In 2000 when the violent land reform program started, the black market rate began to deviate from the official rate. As years went by, the black market premium widened to 600 percent at end2003. As a result, a heavily managed auction system was in place during January 2004-October 2005. The black market rate, however, continued to depreciate after an initial appreciation.

The increasing incidence of ethnic conflicts and the much-publicized consequences of these conflicts have led economists to make a connection between ethnic diversity and economic phenomena like growth and investment (Easterly and Levine, 1997; Alesina et al., 2003; La Porta et al., 1999). Easterly and Levine (1997) found empirical evidence to support their claim that the very high level of ethnic diversity of countries in Africa is an important contributor to their poor economic performance. La Porta et al. (1999) pointed out that ethnic diversity leads to corruption and low efficiency in governments that expropriate from disadvantaged ethnic groups.

In this context, Zimbabwe initiated a fast-track land reform program to redistribute land from white to black farmers in 2000. The program redistributed - often by use of force-over 80 percent of former commercial farmland, changing radically the racial distribution of access to land. Nine thousand farms were listed for acquisition by end-2004, but few farmers were 
compensated and many farms remained unallocated to new settlers. The execution of the land reform was accompanied by significant losses in production. Agricultural output declined by 30 percent during 2000-04 since the land reform led to significant losses in the agricultural capital stock and in production, uneven distribution of land and infrastructure, lack of security of tenure, and impoverishment of a large proportion of former farm workers.

Against this background, the purpose of the paper is twofold: it aims to demonstrate empirically that a depreciation of the currency in the black market had a negative effect on exports and that ethnic tensions adversely affected export performance in Zimbabwe.

The paper is structured as follows. Section II presents the evolution of export performance in Zimbabwe. Section III analyses the determinants of export demand. Section IV compares measures of competitiveness with neighboring countries and, in Section V, policy measures are suggested. Data and definitions are reported in an Appendix.

\section{EXPORT Performance in ZimbabWe}

Export performance is key to the Zimbabwean economy. Trade is a substantial share of GDP and exports are the main source of foreign exchange for the economy. In particular, agricultural exports, which have declined dramatically in recent years, have traditionally been an important driver of growth in the Zimbabwean economy, given the sector's extensive backward and forward linkages. Hence, fostering competitiveness is important for Zimbabwe's long-term growth and external viability.

The growth rate of total exports was high in the second half of the 1990s, but then turned negative since the early 2000s (Table 1). Zimbabwe's export performance was well above the average of African countries in the 1990s due to its comparative advantage in agriculture which was dominated by large commercial farms, and manufacturing. However, following the increasing overvaluation of the currency, export performance dropped off significantly in 20012004, including relative to the average of developing countries and neighboring countries. With the official exchange rate fixed from October 2000 - first at Z\$55=US\$1 and later at Z\$824=US\$1 - until end-2003, the currency became increasingly overvalued, and the authorities responded with a series of ad hoc measures, including the creation of special regimes for tobacco and gold exporters. The introduction of a managed foreign exchange tender system early in 2004 and the gradual relaxation of the surrender requirements on exporters resulted in a de facto depreciation of the official exchange rate, from Z $\$ 824=\mathrm{US} \$ 1$ to Z $\$ 5,700=\mathrm{US} \$ 1$ by end-2004. However, the currency became overvalued again since the demand for foreign exchange continued to pick up. As a consequence, the parallel market premium rose from 13 percent in January 2004 to 53 percent by end-2004. 
Table 1. Export Growth, 1991-2004

(Annual average rate, in percent)

\begin{tabular}{lrrrr}
\hline & $1991-95$ & $1996-00$ & $2001-04$ & $1991-2004$ \\
\hline Zimbabwe & 6.9 & 15.5 & -1.1 & 7.7 \\
World & & & & \\
Developing countries & 12.7 & 4.8 & 9.7 & 7.6 \\
Africa & 2.1 & 7.8 & 12.5 & 10.7 \\
& & 9.2 & 10.7 & 7.1 \\
South Africa & $\ldots$ & $\ldots$ & 11.3 & $\ldots$ \\
Tanzania & 11.4 & 1.9 & 16.1 & 9.4 \\
Kenya & 11.5 & 0.8 & 14.7 & 8.6 \\
Uganda & 38.0 & -4.2 & 17.7 & 17.1 \\
\hline
\end{tabular}

Source: IMF, Direction of Trade Statistics.

The sharp swings in the real exchange rate since 2000 were met with a relatively muted export response, suggesting that other factors may be at play (Figure 1). In contrast to the mineral sector, manufacturing and especially agriculture have been much less responsive to movements in the real effective exchange rate (REER) (Figure 2). Other factors, such as internal conflict, poor infrastructure, access to credit, and poor governance, could have important effects that may limit the positive impact of a more competitive exchange rate. In particular, agricultural production and exports - the mainstay of the Zimbabwean economy - collapsed with the disruption caused by the violent implementation of the fast-track land reform, which saw the seizure of largely white-owned commercial farms. ${ }^{2}$ The manufacturing sector, primarily agroprocessing, was also affected, since a large amount of inputs come from the agricultural sector.

\footnotetext{
2 The collapse of the commercial farming system also resulted in increased reliance on government-supplied inputs (seeds, fertilizers), which have often been delayed (see Ivaschenko (2005)).
} 
Figure 1. Exports and Real Effective Exchange Rate

(In millions of U.S. dollars, unless otherwise indicated)

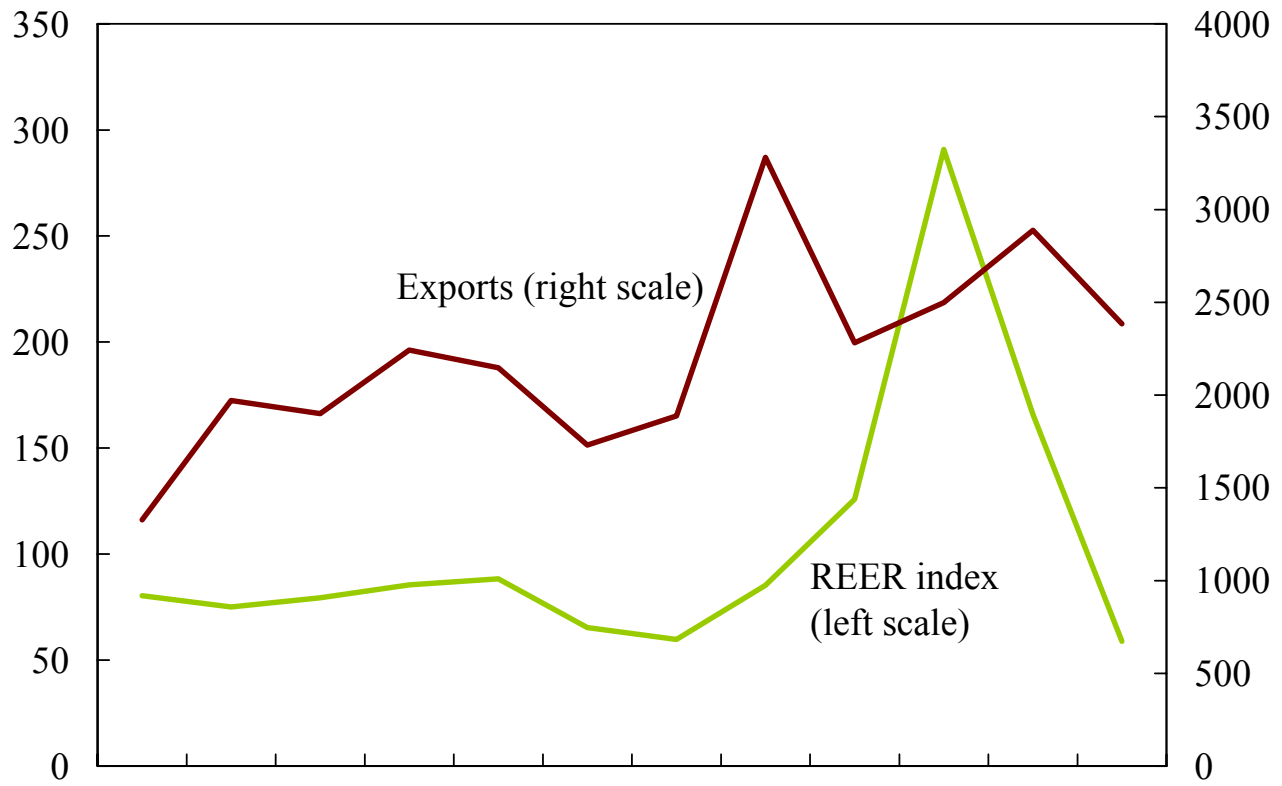

199319941995199619971998199920002001200220032004

Source: IMF, Direction of Trade Statistics and Information Notice System.

Figure 2. Exports by Sector

(In millions of U.S. dollars)

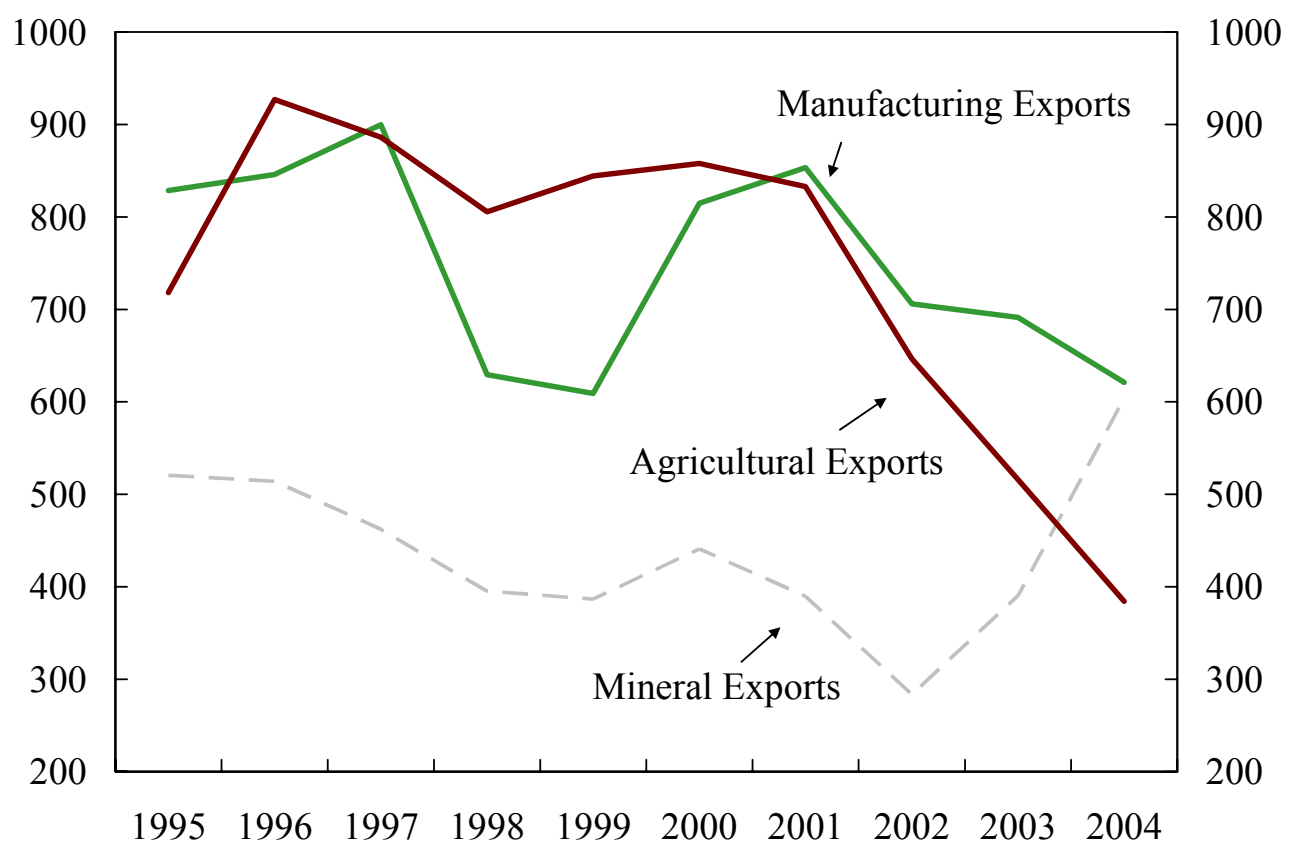

Source: Zimbabwean authorities. 


\section{AnAlysis OF THE DETERMinAnts OF EXPORT BeHAVIOR}

\section{A. Data}

The export data used in this study are drawn from the Direction of Trade Statistics (DOTS) database. The DOTS present current figures on the value of merchandise exports disaggregated according to Zimbabwe's most important trading partners. This analysis uses exports to Zimbabwe's ten major trading partners: United States, Germany, South Africa, United Kingdom, Japan, France, Italy, Netherlands, Canada and Switzerland for the period 1984:Q12004:Q4. The primary source of the rest of the data, with the exception of the black market foreign exchange rates, are IMF data on Zimbabwe. For the parallel exchange rate the data sources are various issues of the World Currency Yearbook (International Currency Analysis, Brooklyn, New York), published before 1983 as the Pick's Currency Yearbook, and Techfin. A description of the data is given in the Appendix.

\section{B. The Model Specification}

The empirical work is based on the imperfect substitutes model proposed by Goldstein and Khan (1985). The major assumption of the model is that neither imports nor exports are perfect substitutes for domestic goods. Exports are imperfect substitutes in world markets for other countries' domestically produced goods, or third countries' exports. According to conventional demand theory, consumers maximize utility subject to a budget constraint. In this respect, export demand is specified as a function of the real exchange rate and the real incomes of the rest of the world. Thus, the export demand equation can be expressed as:

$$
\begin{gathered}
\log Q_{i, t}=\alpha_{i}+\beta_{1} \log I_{i, t}+\beta_{2} \log \bar{R}_{i, t}+u_{i, t}, \quad i=1, \ldots, 10 \quad t=1, \ldots, 84 \\
\beta_{1}>0, \quad \beta_{2}>0
\end{gathered}
$$

where $i$ denotes the ten countries that are the most important trade partners of Zimbabwe and $t$ denotes time. Descriptions of the variables are listed below:

$Q_{i, t}$ : Real exports of Zimbabwe to country $i$.

$I_{i, t}$ : Industrial production index of country $i$ (a proxy for foreign income).

$\bar{R}_{i, t}$ : Real exchange rate of country $i$.

\section{Extended Model}

Given the economic environment in Zimbabwe, the model is extended to include a dual exchange rate regime (with official and parallel markets) as well as non-price factors. Exports to 
the official market (which is measured in the DOTS) are modeled as a function of the real exchange rates in both the official market and parallel market. ${ }^{3}$ Moreover, as noted above, Zimbabwe's export performance likely reflects many factors other than the real exchange rate, such as governance, cost of doing business, quality of infrastructure, and lack of property rights. Consequently, we expand the equation to include qualitative measures of such factors. With the inclusion of these variables explaining export supply, the model becomes a reduced form representation of export behavior.

$$
\begin{gathered}
\log Q_{i, t}=\alpha_{i}+\beta_{1} \log I_{i, t}+\beta_{2} \log R_{i, t}+\beta_{3} \log \bar{R}_{i, t}+\sum \beta_{j} \text { qualindexes }_{t}+u_{i, t} \\
\beta_{1}>0, \quad \beta_{2}<0, \quad \beta_{3}>0, \quad \beta_{j} ?
\end{gathered}
$$

where:

$R_{i, t}:$ Real parallel exchange rate with country $i$.

$\bar{R}_{i, t}$ : Real official exchange rate of country $i$.

qualindexes $_{t}$ : contains measures for corruption, bureaucracy quality, democratic accountability, economic risk, internal conflict, ethnic tensions, law and order, and investment profile.

The model estimations are based on quarterly data between the years 1985-2004. The export demand equation is estimated using a panel data model with random effects. Overall, the signs obtained for the coefficients are consistent with economic theory and are robust to different specifications. $^{4}$

\section{Empirical Results}

According to the estimation results (Table 2), a real exchange rate devaluation would be the most important factor in boosting exports. As the variables are estimated in log form, the coefficients represent elasticities of real export demand.

\footnotetext{
${ }^{3}$ Such a formulation - where the supply of official exports is a function of both the real parallel and real official exchange rates - would be consistent with a model where the variable cost of supplying (or distributing to) the official and parallel markets differ (for a given good), but the same fixed factor is used in production. The (variable) costs of distribution can be measured by domestic prices (see Coorey (1990), p. 178).

${ }^{4}$ Given the times series component of the data, dynamic heterogeneous cointegrated panel data models-which allow for heterogeneity in parameters and dynamics across exports to the different countries - were also estimated. The variables were found weakly integrated of order 1 and formed a cointegrating vector.
} 
Table 2. Econometric Results

\begin{tabular}{|c|c|c|c|}
\hline \multicolumn{4}{|c|}{ Dependent variable: Real official exports } \\
\hline Variables & Estimate $^{1}$ & Std. Err. & Prob \\
\hline Real official exchange rate & $0.110 * *$ & 0.05 & 0.03 \\
\hline Real parallel exchange rate & $-0.262 * * *$ & 0.05 & 0.00 \\
\hline Industrial production index & 0.155 & 0.22 & 0.47 \\
\hline Ethnic tensions & $0.045 * *$ & 0.02 & 0.02 \\
\hline Constant & $1.651 *$ & 0.10 & 0.10 \\
\hline Seasonal dummies & \multicolumn{3}{|c|}{ yes } \\
\hline Random effects & \multicolumn{3}{|c|}{ yes } \\
\hline Wald Chi2 & 77.67 & & 0.00 \\
\hline No. of observations ${ }^{2}$ & \multicolumn{3}{|c|}{840} \\
\hline
\end{tabular}

The elasticity of official exports with respect to a change in the official real exchange rate is 0.11 , while the elasticity with respect to the parallel market real exchange rate is more than double at -0.26 . A depreciation of the official exchange rate generates a positive price effect, which leads to increased export demand in line with the theoretical prediction. The elasticity of export demand with respect to the real parallel exchange rate is negative (as predicted) and highly significant at -0.26 . This result is consistent with the hypothesis that a more depreciated parallel exchange rate provides an incentive to smuggle rather than export through official markets. Exporters can boost their profits by underinvoicing and later on selling the currency corresponding to the underinvoiced amount on the black market, thereby obtaining a greater amount of local money for the same transaction. The larger coefficient on the parallel market real exchange rate suggests that an equal (in percentage terms) depreciation of the official and parallel market rates (which implies a widening of the parallel market premium) results in a shift in exports away from the official market.

The income elasticity is found to be small and insignificant suggesting that exports are insensitive to foreign income.

Ethnic tension is identified as an important determinant of export performance. Different indices measuring political and economic risk components were included in the equation. Some of the indices were perfectly correlated or had coefficient signs that were not robust to the 
specification. Therefore, a generic to specific approach was followed and the ethnic tension index was the only index robust to the specification. According to the rating system of the International Country Risk Guide, the ethnic tension index measures the degree of tension within a country attributable to racial, nationality, or language divisions. ${ }^{5}$ The table 2 shows that the coefficient for ethnic tension is significant, indicating that higher ethnic tensions adversely affect export performance. Given the close link between ethnic tensions and land ownership issues in Zimbabwe, it is plausible that the results reflect the adverse impact on exports of the fast-track land reform.

\section{COMPARATIVE Measures OF COMPETITIVENESS}

This section presents an analysis of other qualitative factors that affect export performance that are difficult to incorporate in the quantitative analysis. It is based on two sources: (i) The Growth Competitiveness Index (World Economic Forum) is composed of three pillars for 104 countries: the quality of the macroeconomic environment, the state of the country's public institutions, and, given the increasing importance of technology in the development process, a country's technological readiness. (ii) The Snapshot of the Business Climate (World Bank) identifies specific regulations and policies that encourage or discourage investment, productivity, and growth and compares Zimbabwe with regional averages. The results are summarized in Table 3.

Zimbabwe's poor macroeconomic and institutional environment lowers its competitiveness compared with other countries in the region. Zimbabwe ranks below neighboring countries in the overall Growth Competitiveness Index due primarily to having the lowest score relative to the other 103 countries on the Macroeconomic Environment Index. Moreover, Zimbabwe also scores worst compared to neighboring countries - with the exception of Uganda - on the Public Institutions Index, which includes, among other factors, measures of corruption and rule of law.

The microeconomic conditions for doing business in Zimbabwe are comparable to regional averages. However, the costs in terms of GNI per capita of starting a business and registering property are higher than the regional average. Zimbabwe's labor market is less rigid than the regional average but performs worse than Zambia, Uganda, and Botswana.

\section{Conclusions}

The evidence gathered in this paper suggests that the overvaluation of the official exchange rate has had a cost for Zimbabwe in terms of competitiveness. Exports, in particular, have been affected by the overvaluation of the exchange rate. The most interesting result of this study is

\footnotetext{
${ }^{5}$ Lower ratings are given to countries where racial and nationality tensions are high because opposing groups are intolerant and unwilling to compromise. Higher ratings are given to countries where tensions are minimal, even though such differences may still exist.
} 
the negative relationship found between the parallel market rate depreciation and the value of legal exports. The paper has also shown that the performance of Zimbabwe's official exports is significantly affected by ethnic tensions.

The importance of exchange rate policies in affecting export performance has been widely recognized and not surprisingly been the linchpin of many structural adjustment programs. The main lessons that emerge from the analysis of the paper can be summarized as follows: policies that give rise to a widening of the parallel market premium (such as maintaining an overvalued exchange rate and lax monetary and fiscal policies) would, other things equal, adversely affect the performance of "official exports." Conversely, exchange rate unification and tight macroeconomic policies can be expected to improve export performance. Similarly, policies that improve governance and reduce ethnic tensions (particularly in this context, an orderly resolution of land issues) can be expected to have a beneficial impact on exports. 
Table 3. Business Climate, 2004

\begin{tabular}{|c|c|c|c|c|c|c|}
\hline Indicator & Zimbabwe & South Africa & Zambia & Uganda & Botswana & $\begin{array}{l}\text { Regional } \\
\text { average }\end{array}$ \\
\hline Growth Competitiveness Index (rank order) & 99 & 41 & 83 & 79 & 45 & $\ldots$ \\
\hline Technology Index & 86 & 40 & 90 & 77 & 64 & $\ldots$ \\
\hline Public Institutions Index & 73 & 35 & 66 & 86 & 39 & $\ldots$ \\
\hline Macroeconomic Environment Index & 104 & 48 & 95 & 75 & 42 & $\ldots$ \\
\hline Business Competitiveness Index & 82 & 25 & 78 & 71 & 62 & $\ldots$ \\
\hline \multicolumn{7}{|l|}{ Starting a business } \\
\hline Number of procedures & 10 & 9 & 6 & 17 & 11 & 11 \\
\hline Duration (days) & 96 & 38 & 35 & 36 & 108 & 60 \\
\hline Cost ( $\%$ of GNI per capita) & 304.7 & 9.1 & 22.8 & 131.3 & 11.3 & 225.2 \\
\hline Min. Capital (\% of GNI per capita) & 53 & 0 & 2.7 & 0 & 0 & 254.1 \\
\hline \multicolumn{7}{|l|}{ Hiring/Firing workers 1/ } \\
\hline Flexibility of hiring index & 11 & 56 & 0 & 0 & 0 & 53.2 \\
\hline Flexibility of firing index & 20 & 60 & 40 & 0 & 40 & 50.6 \\
\hline Firing costs (weeks of wages) & 29 & 38 & 47 & 12 & 19 & 59.5 \\
\hline \multicolumn{7}{|l|}{ Registering Property } \\
\hline Number of procedures & 4 & 6 & 6 & 8 & 6 & 7 \\
\hline Duration (days) & 30 & 20 & 70 & 48 & 69 & 114 \\
\hline Cost (\% property value) & 18.1 & 11.3 & 9.2 & 5.5 & 5 & 13.2 \\
\hline \multicolumn{7}{|l|}{ Getting credit } \\
\hline Cost to create collateral ( $\%$ of income $\mathrm{pc})$ & 2.4 & 2.3 & 19.2 & 11.9 & 2 & 41.8 \\
\hline Legal rights index $2 /$ & 7 & 6 & 6 & 5 & 9 & 4.6 \\
\hline \multicolumn{7}{|l|}{ Protecting Investors } \\
\hline Disclosure Index 3/ & 6 & 6 & 1 & 2 & 5 & 2.1 \\
\hline \multicolumn{7}{|l|}{ Enforcing Contracts } \\
\hline Number of procedures & 33 & 26 & 16 & 15 & 26 & 35 \\
\hline Duration (days) & 350 & 277 & 274 & 209 & 154 & 434 \\
\hline Cost $(\%$ of debt $)$ & 19.1 & 11.5 & 28.7 & 22.3 & 24.8 & 43.0 \\
\hline \multicolumn{7}{|l|}{ Closing a business } \\
\hline Duration (years) & 2.2 & 2 & 2.7 & 2.1 & 2.2 & 3.6 \\
\hline Cost ( $\%$ of estate $)$ & 18 & 18 & 8 & 38 & 18 & 20.5 \\
\hline Recovery rate (cents on the dollar) & 9.2 & 31.8 & 19.4 & 35.5 & 50.9 & 17.1 \\
\hline
\end{tabular}

Source: World Economic Forum and World Bank.

$1 /$ The indices vary from 0 to 100 with higher values representing more rigid regulations.

2 / It ranges from 0 to 10, with higher scores indicating that those laws are better designed to expand access to credit.

3/ The index varies between 0 and 7, with higher values indicating more disclosure. 


\section{Appendix I. Description of Sources and Transformation}

The sources and the way particular variables were defined are as follows:

$Q_{i, t}:$ Real exports of Zimbabwe to country $i$ : Direction of Trade Statistics and International Financial Statistics, IMF.

$I_{i, t}$ : Industrial production index of country $i$ : Real Sector and Government Data (GSTS), IMF.

$\bar{R}_{i, t}:$ Real official exchange rate of country $i$.

$R_{i, t}:$ Real parallel exchange rate with country $i$.

The formulas for the real official exchange rates are as follows:

$R_{i, t}=\frac{e_{i} * P_{i}}{P_{d}}, \quad \bar{R}_{i, t}=\frac{\bar{e}_{i} * P_{i}}{P_{d}}$

where:

$\bar{e}_{i}$ : Nominal official exchange rate with country $i$ : Information Notice System, IMF.

$e_{i}$ : Nominal parallel exchange rate with country $i$ :World Currency Yearbook and Techfin.

$P_{i}$ : Consumer price of country $i$ : Information Notice System, IMF.

$P_{d}:$ Price of domestic goods: Information Notice System, IMF.

qualindexes $_{t}$ : contains measures for corruption, bureaucracy quality, democratic accountability, economic risk, internal conflict, ethnic tensions, law and order, and investment profile:

International Country Risk Guide. 


\section{REFERENCES}

Alesina, A., A. Devleeschauwer, W. Easterly, S. Kurlat and R. Wacziarg, 2003, "Fractionalization," Journal of Economic Growth, Vol. 8, No. 2, pp. 155-194.

Barro, R., 1991, "Economic Growth in a Cross Section of Countries," Quarterly Journal of Economics, Vol. 106, No. 2, pp. 407-443.

Coorey, S., 1990, “Foreign Exchange Rationing in an Exchange Control Regime,” Harvard University, $\mathrm{PhD}$ thesis.

Cotanni, J. A., D. F. Cavallo, and J. S. Khan, 1990, "Real Exchange Rate Behavior and Economic Performance in LDCs," Economic Development and Cultural Change, Vol. 39, No. 1.

De Grauwe, P., 1988, "Exchange Rate Variability and the Slowdown in Growth of International Trade," IMF Staff Papers, Vol. 35, pp. 63-84.

Easterly, W., and R. Levine, 1997, "Africa's Growth Tragedy: Policies and Ethnic Divisions," Quarterly Journal of Economics, Vol. 112, No. 4, pp. 1203-1250.

Edwards, S., 1988, Exchange Rate Misalignment in Developing Countries (Baltimore: The Johns Hopkins University Press).

Frenkel, J. A., and M. S. Khan, 1990, "Adjustment Policies and Economic Development," American Journal of Agricultural Economics, Vol. 72, No. 3, pp. 815-820.

Ghura, D., and T. J. Grennes, 1993, "The Real Exchange Rate and Macroeconomic Performance in Sub-Saharan Africa," Journal of Development Economics, Vol. 42, pp. 155-174.

Goldstein, M., and M. S. Khan, 1985, "Income and Price Effects in Foreign Trade," Handbook of International Economics, Vol. II, Chapter 20.

International Currency Analysis, 1993, World Currency Yearbook.

Ivaschenko, O., 2005, "Land Reform, Agricultural Policies, and Outcomes," in Zimbabwe: Selected Issues and Statistical Appendix, IMF Country Report No. 05/359 (Washington: International Monetary Fund).

La Porta, R., F. Lopez-de-Silanes, A. Sheifer, and R. Vishny, 1999, “The Quality of Government," Journal of Law, Economics, and Organization, Vol. 15, No. 1, pp. 222-79. 
Muñoz, S., 2005, "Export Performance: The Impact of the Parallel Market and Governance Factors," in Zimbabwe: Selected Issues and Statistical Appendix, IMF Country Report No. 05/359 (Washington: International Monetary Fund).

Reif, T., 2004, "External Competitiveness and Export Performance in Tanzania," in Tanzania: Selected Issues and Statistical Appendix, IMF Country Report No. 04/284 (Washington: International Monetary Fund).

Rodrik, D., 1999, "Where Did All the Growth Go? External Shocks, Social Conflict, and Growth Collapses?," Journal of Economic Growth, Vol. 4, pp. 385-412.

Wood, A., and K. Jordan, 2000, "Why Does Zimbabwe Export Manufactures and Uganda Not? Econometrics Meets History," Journal of Development Studies, Vol. 37, Number 2. 